\title{
Preservative Effects of Different Treatments and Their Flavor Acceptability in Cashew Apple and Pineapple Blend Juice Gninfanni Silvère OUATTARA ${ }^{1 *}$, Doudjo SORO ${ }^{2}$, Mohamed Anderson YEO $^{3}$, Ernest Kouadio $\mathrm{KOFFI}^{4}$
}

\author{
${ }^{1,4}$ Laboratoire de Biochimie et Sciences des Aliments, UFR Biosciences, Université Félix Houphouët-Boigny, UFHB 01 BP \\ V 34 Abidjan, Côte d'Ivoire. \\ ${ }^{2}$ UMRI Sciences des Procédés chimiques Alimentaires et Environnementaux, Institut National Polytechnique Félix \\ Houphouët-Boigny (INP-HB), BP 1313 Yamoussoukro, Côte d'Ivoire. \\ ${ }^{3}$ UFR d'Ingénierie agronomique, Forestière et Environnementale, Université de Man, BP 20 Man, Côte d'Ivoire.
}

\begin{abstract}
The aim of this study is to evaluate the stability of a cashew apple and pineapple blend juice (25:75 v / v). Various treatments were applied, including pasteurization (92 C, $15 \mathrm{~min})$, aqueous extract of ginger (2.5 and 10\%) and potassium sorbate $(1 \mathrm{~g} / \mathrm{kg})$. The physicochemical results revealed that the addition of the aqueous extract of ginger caused an increase in the content of ascorbic acid, total sugars, proteins and minerals such as magnesium, potassium, phosphorus and zinc. The microbiological analysis showed lower microbial counts of the treated samples compared to the control. The different treatments could have an antimicrobial effect. The sensory analysis reveals a general acceptability for all the samples formulated. This acceptability value is higher for the sample supplemented with $10 \%$ aqueous extract of ginger. With a view to preservation without chemical preservatives while improving nutrient content, the $10 \%$ aqueous ginger extract could help extend the shelf life of fruit juice drinks.
\end{abstract}

Keywords_Drink, pineapple, cashew apple, preservatives, quality.

\section{INTRODUCTION}

Ivory Coast is the leading producer of cashew nuts since 2015 with a production of 725000 tons (CCA, 2016). Cashew apple, a pseudo fruit of the cashew tree, is rich in vitamins C, polyphenols (Michodjehoun-Mestres et al., 2009) and also contains a significant amount of carotenoids (Assunção and Mercadante 2003, Abreu 2012). However, almost all cashew apples are lost at harvesting sites because of their astringency and certain taboos (Soro et al., 2008). To remedy this, a drink formulation containing cashew apple and pineapple juice was produced. Pineapple (Ananas comosus) is a non-astringent, less acidic fruit that is mature and consumed much in the world. Moreover, in the fresh state, it contains several enzymes including bromelain which facilitates the digestion and assimilation of proteins, by fractionating the amino acid chains (Sekhar et al., 2013). Thus, the mixture of the two fruit juices can result in a product enriched with vitamins, minerals and good sensory characteristics when compared to the starting raw materials (Akinwale 2000, Rodrigo et al 2003, Jain and Khurdiya 2004). Like all fruit juices, this drink must retain its organoleptic and microbiological qualities over time. Indeed, one of the difficulties for the large-scale production of fruit juices is their stability. The same is true for unstabilized cashew apple juice, which has a very short shelf life because yeast attacks the juice and fermentation even at refrigeration temperature.

There is a need to explore several methods of stabilization to extend the shelf life of juices. Thus, the use of certain chemical preservatives such as sorbate and benzoate improves the shelf life of beverages (Dougheri et al., 2007, Nwachukwu and Ezeigbo, 2013). However, the use of chemical preservatives in nutrition tends to have detrimental effects on consumer health (Adesokan et al., 2010). Also, the current trend is towards biological preservatives (aliu et al., 2007). Among these biological preservatives, ginger (zingiber officinale) is traditionally used as a spice in preparations (Kolapo et al., 2007) for its antioxidant and antimicrobial activity. According to Smith-Palmer et al. (1998), ginger has a bactericidal effect against E. coli and Streptococcus.

The objective of this study is to assess the preservative effects of different treatments and their flavor acceptability in cashew apple and pineapple blend juice. 


\section{MATERIALS AND METHODS}

\subsection{Biological materiel}

The plant material used consists of cashew apples (Anacardium occidentale L. Anacardiaceae), pineapple (Ananas comosus) and rhizomes of ginger (zingiber officinale). The cashew apples used, made up of red and yellow apples, came from the center of Cote d'Ivoire. The pineapple used is of smooth Cayenne variety in the mature stage. Pineapple and ginger rhizomes were purchased at the large market in Yamoussoukro, Côte d'Ivoire.

\subsubsection{Preparation of the aqueous extract of ginger}

The ginger rhizomes were washed four times with drinking water. They were stripped of their peels using a sterile stainless steel knife. The rhizomes were then cut into dice and then dried in the shade. The ginger was then pulverized. The powder obtained was dissolved in $50 \mathrm{ml}$ of distilled water and then washed with $100 \mathrm{ml}$ of distilled water and filtered with a muslin cloth. The obtained solution was evaporated to obtain a dry extract which was dissolved in $100 \mathrm{ml}$ of distilled water to obtain the aqueous extract of ginger. This extract was stored in pre-sterilized glass bottles in a refrigerator at $4{ }^{\circ} \mathrm{C}$ until use.

\subsubsection{Extraction of cashew apple juice}

The fruits harvested consist of apples and cashews. The apples were carefully separated from the nuts by means of a wire attached at both ends by small pieces of wood to avoid damaging them. The apples obtained were soaked in chlorinated water at $100 \mathrm{ppm}$ of active chlorine for 20 minutes and then rinsed with potable water. The grinding was carried out using a screw press (ZBK220077-88 LW74d (B) A (China). This press has a power of $4.4 \mathrm{~kW}$ with a rotation speed of the screw of $1440 \mathrm{rpm} . \mathrm{min}-1$. The juice was then filtered with a mesh screen of $1 \mathrm{~mm}$ in diameter and then packed in 5-liter cans and stored at $-10^{\circ} \mathrm{C}$. before the cocktail was formulated.

\subsubsection{Extraction of pineapple juice}

The pineapples were soaked in $100 \mathrm{ml}$ chlorine bleach for 20 minutes and then rinsed with clean water. After washing, the pineapples were peeled, cut and then crushed using the same pulp press ZBK220077-88LW74d (B) A (China). The juice expressed was filtered with a mesh screen of $1 \mathrm{~mm}$ diameter under aseptic conditions and then packed in 5 liter cans and stored in a cold room at $-10^{\circ} \mathrm{C}$. before the various formulations of the cocktail.

\subsubsection{Formulation of cashew apple and pineapple beverage}

The cashew apple and pineapple juices were mixed in 25:75 (v/v) proportions respectively to have the cashew apple and pineapple drink. To this formulated beverage various stabilizers including, aqueous ginger extract at concentrations of 2.5 and $10 \%$, potassium sorbate at $1 \mathrm{~g} / \mathrm{kg}$. Five (5) formulations were obtained with the various stabilizers, namely the control formulation E0; Formulation EG2.5 containing 2.5\% aqueous extract of ginger; The formulation EG10 containing $10 \%$ ginger; The EP formulation which is the pasteurized beverage sample and the ES formulation containing potassium sorbate $(1 \mathrm{~g} / \mathrm{kg})$. The various samples were placed in PET bottles (polyethylene terephthalate) and stored at $4{ }^{\circ} \mathrm{C}$.

\subsection{Physico-chemical analyses}

Ascorbic acid was extracted in the presence of a metaphosphoric acid / acetic acid solution and assayed by standard vitamin C 2.6-dichlorophenol indophenols method (Poncracz et al., 1971).

The $\mathrm{pH}$ was determined at $25^{\circ} \mathrm{C}$. Using an ATC pH-Meter professional pH-013 according to the method described by AOAC (1990).

The total sugar content was determined according to the phenol-sulfuric method as described by Dubois et al. (1956)

Proteins were determined by the Kjedahl method (BIPEA, 1976).

The following minerals: Iron, Potassium, Sodium, Magnesium, Copper, Manganese and Zinc were assayed by a Varian Spectr AA-20 atomic absorption spectrometer using the AOAC 1990 method and Abulude et al. (2007).

\subsection{Microbiological analyses}

Microbiological analysis consisted of counting mesophilic aerobic germs. The count of these organisms was carried out on standard agar for counting, Plate Count Agar (PCA) according to the French standard V 08-051. (AFNOR, 1991). PCA 
(Plate Count Agar) agar used for counting the total flora was cast into the Petri dish. The incubation was then carried out at $37^{\circ} \mathrm{C}$. for $24 \mathrm{~h}$ after serial dilutions.

\subsection{Sensory analysis}

Samples of formulated drinks were analyzed by a panel of fifteen (15) members who are familiar with fruit juices. This panel is composed of students (women and men) from the National Polytechnic Institute of Yamoussoukro. The samples were evaluated using a scale from 0 to 10; with 0 for descriptor not perceived and 10 for descriptor extremely intense.

\subsection{Statistical analysis}

The statistical analysis was carried out by the software Statistica 7.1. Data were subjected to a one-way ANOVA, and means were compared by a Student Newman Keuls test with a significance threshold of $5 \%$.

\section{RESULTS}

The results of Table 1 show the physicochemical composition of the various drinks based on cashew apples and pineapples, supplemented or not with aqueous extract of ginger and potassium sorbate.

TABLE 1

Physicochemical Characterization of Cashew Apple and Pineapple Juice Blends Pasteurized OR SUPPLEMENTED WiTH GINGER EXTRACTS OR POTASSIUM SORBATE (1g/kg)

\begin{tabular}{|c|c|c|c|c|c|}
\hline & E0 & EG2,5 & EG10 & $\mathbf{E P}$ & $\mathbf{E S}$ \\
\hline Vitamin C (mg/100g) & $54,38 \pm 3,12^{c}$ & $64,34 \pm 10,38^{\mathrm{a}}$ & $78,68 \pm 3,29^{d}$ & $46,9 \pm 2,74^{b}$ & $64,34 \pm 2,19^{a}$ \\
\hline pH & $3,61 \pm 3,61^{\mathrm{b}}$ & $3,58 \pm 0,014^{\mathrm{a}}$ & $3,6 \pm 0,007^{\mathrm{c}}$ & $3,7 \pm 0,007^{\mathrm{d}}$ & $4,33 \pm 0,014^{\mathrm{e}}$ \\
\hline Total sugars (mg/100mL) & $150,75 \pm 5,3^{\mathrm{ab}}$ & $220,5 \pm 4,24^{\mathrm{cd}}$ & $165,5 \pm 13,43^{b}$ & $141,75 \pm 1,06^{\mathrm{a}}$ & $207,75 \pm 3,18^{\mathrm{c}}$ \\
\hline Proteins (\%) & $1,23 \pm 0,07^{\mathrm{a}}$ & $2,15 \pm 0,07^{\mathrm{c}}$ & $2,59 \pm 0,05^{\mathrm{d}}$ & $1,97 \pm 0,014^{\mathrm{b}}$ & $1,23 \pm 0,007^{\mathrm{a}}$ \\
\hline $\mathrm{Mg}^{2+}(\mathrm{mg} / 100 \mathrm{~mL})$ & $888,6 \pm 4,52^{a}$ & $872 \pm 2,54^{\mathrm{a}}$ & $907,3 \pm 8,06^{\mathrm{a}}$ & $728 \pm 1,69^{b}$ & $913 \pm 64,62^{a}$ \\
\hline $\mathrm{K}^{+}(\mathrm{mg} / \mathrm{L})$ & $1371,6 \pm 29,13^{\mathrm{a}}$ & $1227,3 \pm 3,25^{\mathrm{c}}$ & $1661,2 \pm 29,13^{b}$ & $1370,3 \pm 8,9^{\mathrm{a}}$ & $1687,1 \pm 15,41^{b}$ \\
\hline $\mathrm{Ca}^{2+}(\mathrm{mg} / \mathrm{L})$ & $306,3 \pm 9,47^{\mathrm{d}}$ & $282,2 \pm 0,28^{\mathrm{ab}}$ & $199 \pm 0,28^{\mathrm{c}}$ & $288,6 \pm 1,41^{\mathrm{b}}$ & $271,3 \pm 0,42^{\mathrm{a}}$ \\
\hline $\mathrm{Fe}^{2+}(\mathrm{mg} / \mathrm{L})$ & $3,08 \pm 0,1^{\mathrm{a}}$ & $2,92 \pm 0,12^{\mathrm{a}}$ & $3,77 \pm 0,48^{\mathrm{c}}$ & $2,06 \pm 0,04^{b}$ & $2,89 \pm 0,08^{\mathrm{a}}$ \\
\hline$P(\mathbf{m g} / \mathrm{L})$ & $26,5 \pm 0,7^{\mathrm{a}}$ & $65 \pm 2,12^{c}$ & $105 \pm 1,41^{\mathrm{d}}$ & $25,5 \pm 0,7^{\mathrm{a}}$ & $59,5 \pm 0,7^{\mathrm{b}}$ \\
\hline $\mathrm{Zn}^{2+}(\mathrm{mg} / \mathrm{L})$ & $0,40 \pm 0,02^{b}$ & $0,82 \pm 0,03^{\mathrm{c}}$ & $1,04 \pm 0,04^{\mathrm{d}}$ & $0,31 \pm 0,007^{\mathrm{a}}$ & $0,33 \pm 0,01^{\mathrm{a}}$ \\
\hline
\end{tabular}

Means with different letters in the same row indicate significant differences $(P \leq 0.05)(n=3)$. EO: control drink; E2.5: beverage supplemented with $2.5 \%$ aqueous extract of ginger; EG10: drink supplemented with 10\% aqueous extract of ginger; EP: pasteurized drink; ES: beverage supplemented with potassium sorbate.

The ascorbic acid content varies from $46.9 \mathrm{mg} / 100 \mathrm{ml}$ for the pasteurized drink (EP) to $78.6 \mathrm{mg} / 100 \mathrm{ml}$ for the beverage preserved with $10 \%$ aqueous extract of ginger. The $\mathrm{pH}$ value varies from 3.58 for the sample EG2.5 (cashew apple and pineapple beverage supplemented with 2.5\% aqueous ginger extract to 4.33 for sample ES (Beverage based on cashew apple and pineapple supplemented with potassium sorbate. There is a significant difference at $\mathrm{P}<0.05$ between the different values of the total sugars of the different drink samples. The total sugars vary from $141.75 \mathrm{mg} / \mathrm{ml}$ for the EP sample (cashew apple and pasteurized pineapple drink without addition of aqueous extract or sorbate) to $220.5 \mathrm{mg} / \mathrm{ml}$ for sample E2.5. Protein content was significantly higher in the sample supplemented with $10 \%$ ginger, which ranged from $1.23 \%$ for sample E0 (cashew apple and pineapple beverage without addition of aqueous extract or Sorbate) to 2.59\% for the E10 sample. Cashew apple and pineapple have varying concentrations of metal ions $\mathrm{Mg}^{2+}, \mathrm{K}^{+}, \mathrm{Ca}^{2+}, \mathrm{Fe}^{2+}, \mathrm{Na}^{+}$, and $\mathrm{Zn}^{2+}$. The cashew apple and pineapple drink supplemented with $10 \%$ aqueous ginger extract has higher iron, phosphorus and zinc contents.

Figure 1 shows the results in $\mathrm{CFU} / \mathrm{ml}$ of the mesophilic aerobic germs counted on the first, fourth and seventh day of storage. These results show that the control sample exhibits an exponential increase in germs during the storage days compared to the treated drink samples. This microbial growth ranges from $4.4 \times 10^{3}$ for the first day to $8.2 \times 10^{5}$ for the seventh day of storage. 


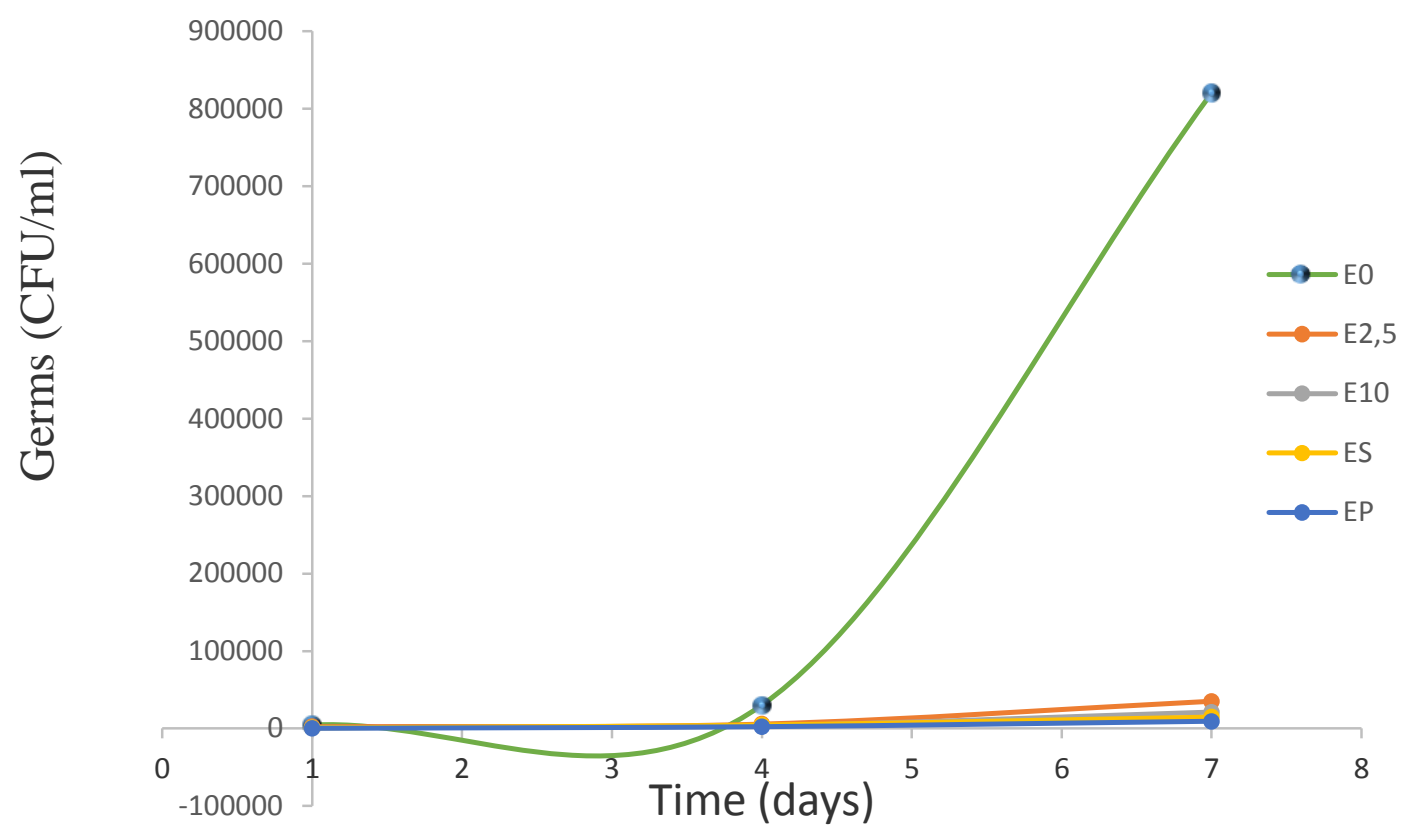

\section{FIGURE 1: MESOPHILIC AEROBIC GERMS GROWTH OF VARIOUS CASHEW APPLE AND PINEAPPLE BLEND JUICES PASTEURIZED OR SUPPLEMENTED WITH AQUEOUS EXTRACT OF GINGER OR POTASSIUM SORBATE DURING STORAGE}

EO: control drink; E2.5: beverage supplemented with 2.5\% aqueous extract of ginger; EG10: drink supplemented with 10\% aqueous extract of ginger; EP: pasteurized drink; ES: beverage supplemented with potassium sorbate.

The organoleptic properties of the beverages studied are presented in Table 2. From these results it emerged that the E10 sample had an overall acceptability of 7.2 against 5.5 for the sample E0.

TABLE 2

MEAN SENSORY EVALUATION SCORES OF THE VARIOUS CASHEW APPLE AND PINEAPPLE BLEND JUICES PASTEURIZED OR SUPPLEMENTED WITH AQUEOUS EXTRACT OF GINGER OR POTASSIUM SORBATE.

\begin{tabular}{|lccccccccccc|}
\hline & \multicolumn{2}{c}{ Color } & \multicolumn{2}{c}{ Fluidity } & \multicolumn{2}{c}{ Appearance } & \multicolumn{2}{c|}{ Taste } & \multicolumn{3}{c|}{ Acceptability } \\
\hline & day1 & day7 & day1 & day7 & day1 & day7 & day1 & day7 & day1 & day7 \\
\hline E0 & $5,5^{\mathrm{a}}$ & $4,4^{\mathrm{a}}$ & $7,8^{\mathrm{a}}$ & $7,5^{\mathrm{a}}$ & $8,5^{\mathrm{a}}$ & $7^{\mathrm{a}}$ & $8,25^{\mathrm{a}}$ & $7^{\mathrm{a}}$ & $5,5 \mathrm{a}$ & $4^{\mathrm{a}}$ \\
$\mathbf{E 2 , 5}$ & $6,4^{\mathrm{a}}$ & $5,4^{\mathrm{a}}$ & $6,5^{\mathrm{a}}$ & $5,5^{\mathrm{a}}$ & $6^{\mathrm{a}}$ & $5,5^{\mathrm{a}}$ & $5,9^{\mathrm{a}}$ & $5,3^{\mathrm{a}}$ & $6^{\mathrm{a}}$ & $5,5^{\mathrm{a}}$ \\
$\mathbf{E 1 0}$ & $7,7^{\mathrm{a}}$ & $6,7^{\mathrm{a}}$ & $6,3^{\mathrm{a}}$ & $5^{\mathrm{a}}$ & $6,9^{\mathrm{a}}$ & $6,3^{\mathrm{a}}$ & $6,3^{\mathrm{a}}$ & $5,3^{\mathrm{a}}$ & $7,2^{\mathrm{a}}$ & $6,5^{\mathrm{a}}$ \\
$\mathbf{E S}$ & $4,8^{\mathrm{a}}$ & $4,5^{\mathrm{a}}$ & $7,8^{\mathrm{a}}$ & $7,5^{\mathrm{a}}$ & $6,9^{\mathrm{a}}$ & $6,5^{\mathrm{a}}$ & $7,5^{\mathrm{a}}$ & $7^{\mathrm{a}}$ & $6,5^{\mathrm{a}}$ & $6^{\mathrm{a}}$ \\
$\mathbf{E P}$ & $5,5^{\mathrm{a}}$ & $4,8^{\mathrm{a}}$ & $7,5^{\mathrm{a}}$ & $7^{\mathrm{a}}$ & $6,5^{\mathrm{a}}$ & $6^{\mathrm{a}}$ & $7^{\mathrm{a}}$ & $6,5^{\mathrm{a}}$ & $6,2^{\mathrm{a}}$ & $6^{\mathrm{a}}$ \\
\hline
\end{tabular}

Means with different letters in the same row indicate significant differences $(P \leq 0.05)(n=3)$

EO: control drink; E2.5: beverage supplemented with 2.5\% aqueous extract of ginger; EG10: drink supplemented with 10\% aqueous extract of ginger; EP: pasteurized drink; ES: beverage supplemented with potassium sorbate.

\section{DISCUSSION}

The ascorbic acid contents of the different cashew apple and pineapple beverage formulations supplemented or not with aqueous extract of ginger or sorbate vary from $54.38 \mathrm{mg} / 100 \mathrm{ml}$ for the formulation E0 to $78.68 \mathrm{mg} / 100 \mathrm{ml}$ for the EG10 formulation. The beverage stabilized with $10 \%$ of the aqueous ginger extract had a significantly elevated ascorbic acid content $(\mathrm{P}<0.05)$. Thus the ascorbic acid content can be increased by addition of the aqueous extract. This increase in the ascorbic acid content by addition of aqueous extract is comparable to the results of Yeo et al. (2014) on the analysis of the 
quality attributes of a banana juice beverage supplemented with aqueous ginger extract. These results clearly show us that ginger spices are rich in ascorbic acid.

The protein content was significantly higher for the formulation containing the aqueous ginger extract. The $2.5 \%$ formulation contains $2.15 \%$ versus $2.59 \%$ protein for the $10 \%$ formulation of aqueous extract. These results are similar to those of Adesokan et al. (2005) and Olayemi et al. (2011). Ginger could be used to improve the vegetable protein content of fruit juice drinks.

The mineral contents evaluated show that the various formulations contain several minerals including magnesium, potassium, calcium, iron, phosphorus and zinc. The formulation of the cashew apple and pineapple beverage supplemented with $10 \%$ aqueous ginger extract has high levels of iron, phosphorus and zinc. These minerals are well known for their beneficial action on human organisms (Institute of Medicine, 2001).

The microbial load of the $10 \%$ aqueous ginger extract formulations increased from $1.2 \times 10^{3}$ on the first day to $2.1 \times 10^{4}$ germs on the seventh day. For the pasteurized formulation, this load increased from 200 germs to $2.3 \times 10^{3}$ compared to 4.4 $\times 10^{3}$ to $8.2 \times 10^{5}$ germs for the sample without treatment (control) (E0). This rapid growth of germs is responsible for the spoilage of cashew apple and pineapple blend juices.

Mesophilic aerobic germs or total mesophilic aerobic flora are good indicators of the general quality and stability of products and the quality (cleanliness) of production facilities (Guiraud, 1998).

The samples supplemented with the aqueous ginger extract have lower microbial loads compared to the control sample E0. A decrease in germs was observed with increasing ginger concentration. The same result was observed in the pasteurized sample but this would decrease its content of thermosensitive elements. This loss would be detrimental to the nutritional quality of the formulation. Ginger may therefore have an antimicrobial effect which has helped reduce the microbial load of the cashew apple juice and pineapple supplemented with it. These results are comparable to those of several researchers (Smith-Palmer et al. 1998, Ayo et al. 2003, Omoya and Akharaiyi, 2012) on the stability of pineapple juice.

The sensory analysis of cashew apple and pineapple blend drinks shows that the formulation with $10 \%$ ginger extract has the highest acceptability. This could be explained by the spicy taste of that sample.

\section{CONCLUSION}

The results obtained in this study clearly indicate the potential of ginger to extend the shelf life of a cashew apple and pineapple blend beverage. Supplementation with $10 \%$ aqueous ginger extract could be a good preservative of fruit juice and beverage thanks to a better antimicrobial effect compared to the $2.5 \%$ aqueous extract. In addition, ginger could be used to boost the nutritional quality of tropical fruits drinks while increasing their shelf life. In addition to having satisfactory biochemical properties, ginger has organoleptic qualities popularly accepted. However, the practice of good hygiene during the preparation of beverages and fruit juices should be adopted to avoid significant microbial contamination.

\section{DISCLOSURE OF INTEREST}

The authors declare that they have no competing interest.

\section{REFERENCES}

[1] Abreu, D., Pinto, Fernando, Antonio (2012). Etude d'un procédé intégrant la microfiltration tangentielle pour la production d'extraits concentrés en caroténoïdes à partir de pommes de cajou. Sciences des procédés - Sciences des aliments. Montpellier, Université de Montpellier 2. Doctorat: 98 pages.

[2] Abulude F.O, Ogunkoya M.O, Adesanya W.O. (2007). Description and performance evaluation of juice extraction constructed in Nigéria. Res.J.Appl.Sci.2:1-34.

[3] Adesokan I.A. (2005). Characterization of killer yeasts from Nigerian traditional fermented alcoholic beverages. M.Sc. Thesis, Department of Microbiology, University of Ibadan, Nigeria.

[4] Adesokan I.A, Abiola I.P, Ogundiya MO (2010). Influence of ginger on sensory properties and shelf - life of Ogi, a Nigerian traditional fermented food. Afr. J. Biotechnol. 9(12):1803-1808.

[5] AFNOR, (1991). Association Française de Normalisation. Recueil des normes françaises des fruits et des produits fruitiers. Troisième édition. pp 411-422.

[6] Akinwale, T.O. (2000). Cashew apple juice: Its use in fortifying the nutritional quality of some tropical fruits. Eur. Food Res. Technol. 211, 205-207. 
[7] Aliu J, Gun I.U, Mustapha A. (2007). Effects of Plant extracts on microbial growth, colour change and lipid oxidation in cooked beef. Food Microbiol. 24:7-14.

[8] A.O.A.C. (1990). Official methods of Analysis (15th Ed.). Association of Official Analytical Chemist, W ashington D.C.

[9] Assunção, R. B. and A. Z. Mercadante A.Z. (2003). "Carotenoids and ascorbic acid composition from commercial products of cashew apple (Anacardium occidentale L.)." Journal of Food Composition and Analysis 16(6): 647-657.

[10] Ayo J. A. and Iheanacho T.N. (2003). Effect of spices on the microbial and sensory quality of Kunun-zaki. Proceedings of the 27th Annual NIFST Conference, p.233.

[11] BIPEA (1976). Bureau International d'Etude Analytique. Recueil des méthodes des communautés Economiques Européennes $1^{\text {ère }}$ Edition, Bruxelles, pp. 67-114.

[12] CCA (2016). Conseil Coton Anacarde en Côte d'Ivoire. Publié le lundi 15 février.

[13] Dubois M., Gilles K., Hamilton J., Rebers P. \& Simith F. (1956). Colorimetric method for determinations of sugars and related substances. Analytical Chemistry, $280: 350-356$.

[14] Dougheri, J.H., Alabi, G. and Elmahmood, A.M. (2007). Effect of some chemical preservatives on the shelf-life of Zobo drink, African Journal of Microbiology Research; 2: 37-41.

[15] Guiraud J P. (1998). Microbiologie des principaux produits alimentaires. In : Microbiologie Alimentaire, Technique de Laboratoire. 1ère ed., Dunod, Paris, France, 280 p.

[16] Institute of Medicine 2001. Food and Nutrition Board, National Academies.

[17] Jain, S.K. and Khurdiya, D.S. (2004) Vitamin C enrichment of fruit juice based ready-to-serve beverages through blending of Indian gooseberry (Emblica officinalis Gaertn.) juice. Plant Foods Hum. Nutr. 59, 63-66.

[18] Kolapo A.L, Popoola T.O.S, Sanni MO, Afolabi R.O. (2007). Preservation of soybean daddawa condiment with dichloromethane extract of ginger. Res. J. Microbiol. 6:13-18.

[19] Michodjehoun-Mestres, L. (2009). Etude des composés phenoliques de la pomme cajou (Anacardium occidentale L.). Biochimie, chimie et technologie alimentaire. Montpellier, Université Montpellier II. Thèse de Doctorat: 97 pages.

[20] Nwachukwu, E. and Ezeigbo, C. G. (2013). Changes in the microbial population of pasteurized soursop juice treated with benzoate and lime during storage. African Journal of Microbiology Research, 7(31): 3992-3995.

[21] Olayemi F, Adedayo R, Muhummad R, Bamishaiye E (2011). The nutritional quality of three varieties of zobo (Hibiscus sabadariffa) subjected to the same preparation condition. Plant Food Hum. Nutr. 6:10-15.

[22] Omoya, F.O. and Akharaiyi, F.C. (2012). Mixture of honey and ginger extract for antimicrobial assessment on some clinical isolates, International Research Journal of Pharmaceuticals; 2 (5): 127-132.

[23] Poncracz G. (1971). Neue potentiometrische Bestimmungsmethoden für Ascorbinsäure und dessen Verbindungen Fresenius Z. Anale of Chemistry $253: 271-274$.

[24] Rodrigo, D., Barbosa-Canovas, G.V., Martinez, A. and Rodrigo, M. (2003). Pectin methyl esterase and natural microflora of fresh mixed orange and carrot juice treated with pulsed electric fields. J. Food Prot. 66, 2336-2342.

[25] Sekhar GS., Rajkeshwar P. and P. Anil. (2013). In Silico Analysis of Stem Bromelain. International Journal OF Pharmaceutical and Chemical Sciences, 2(2): 992-997.

[26] Smith-Palmer, A., Stewart, J. and Fyte, L. (1998). Antimicrobial properties of plant essential oil against five important food borne pathogen, Letters in Food Microbiology; 26: 112-118.

[27] Soro D. (2008). Concentration par microfiltration tangentielle et caractérisation d'extraits carotenoïdiques de pomme de cajou. Institut des régions chaudes. Montpellier, SupAgro. Master Recherche Naval: 67 pages.

[28] Yeo M., Chatigre O., Elleingand E., Koni P. and Koffi E. (2014). Analysis of quality attributes of banana drinks blended with aqueous extracts of ginger. Afr. J. Food Sci. 8(5): 260-263. 